Foundation (NSF), stimulus money has allowed managers to fund a backlog of individual grants and accelerate planning for major infrastructure projects such as the NSF's real-time ocean observatory (see go.nature.com/aV6ZIF).

This is all to the good. The problem, however, is that the party will soon be over: the unexpected influx of funds will largely end a year from now. US science as a whole could all too easily hurtle over the same cliff from which the NIH fell in 2003, when a doubling of its budget over five years came to a sudden end and young investigators who had been drawn into the research pipeline during the boom years suddenly found themselves scrambling for grants in hypercompetitive lean years.

The Obama administration is hoping to avoid a repeat of that meltdown by asking Congress to double the budgets of basic-research agencies over ten years - presumably a more sustainable pace of increase. But it's far from clear whether Congress will grant such a request, or even whether such funds are warranted. In fact, one helpful project coming from the stimulus funds is an NSF programme to study the effects of short-term boosts in science and technology funding on society at large - in effect, using stimulus money to study the stimulus itself. Results, however, are not due for at least two years.

In the meantime, institutions and individual researchers need to prepare now for the end of the largesse. Too many institutions have been content just to feed at the stimulus trough, encouraging their researchers to resurrect long-dead grant proposals and resubmit them without questioning the potential pain for students and staff when the monies disappear again. Instead, universities should be thinking strategically about what actions they can take now to alleviate that pain when it comes. Such actions might include finding ways to structure the funding flow by carrying out expensive data-taking tasks now, while providing support for graduate and postdoctoral students that goes beyond the end of the stimulus.

Scientific societies and professional organizations can also help, by sending out fewer congratulatory notes about landing stimulus funding and instead urging their members to think cleverly about what to do in the aftermath. Other innovative ways about how to keep the stimulus from going to waste can be found on page 876 , where high-level experts weigh in with their views.

There is no mystery about the pain that will come when funding shrinks back down. The time to start planning is now.

\title{
Caught on camera
}

\section{What to do when you are interviewed for an unscientific documentary.}

$\int^{\mathrm{t}}$ tephen Schneider, a climatologist at Stanford University in Palo Alto, California, has always had to deal with angry e-mails from people who think that global warming isn't happening, and that Schneider is part of a conspiracy to promote it. He has been vocal about the dangers of climate change for decades.

In the past week, however, Schneider has been deluged by furious messages. They have been provoked by a clip circulating on the Internet from Not Evil Just Wrong, a documentary film claiming that global-warming fears are 'hysteria'. The clip explains how Schneider did an interview - and then how the university informed the film-makers that it had rescinded permission for using any of the Stanford footage and that Schneider had withdrawn permission to use his name or interview. Schneider says he backed out when he realized that the film-makers were polemicists who had lied to him about their intentions. Some climate-sceptic commentators are accusing him of censorship.

Schneider is by no means the first scientist to feel hoodwinked by film-makers. British evolutionary biologist Richard Dawkins ended up in Expelled: No Intelligence Allowed, a film purporting to show how academics who do not accept evolution are frozen out of academia. Dawkins says that he was conned - that the film-makers had presented the project to him as an even-handed effort entitled Crossroads: The Intersection of Science and Religion. Carl Wunsch, an oceanographer at the Massachusetts Institute of Technology in Cambridge, felt he was "swindled" in a like manner by the producers of The Great Global Warming Swindle. And Nikos Logothetis of the Max Planck Institute for Biological Cybernetics in Tübingen, Germany, let a seemingly objective film crew into his primate laboratory - only to see the footage used in an animal-rights documentary that slams him as cruel.

For many scientists, the natural response to such stories is to stop talking to the media. But that would be an overreaction. For one thing, such misrepresentations are rare. Schneider estimates that he has given some 3,500 interviews since the 1970s, and only twice has he been "set up". Most journalists and documentarians are honestly trying to report the facts, and scientists have a responsibility to tell the public about their work - especially if it is supported by public money.

Fortunately, scientists can do much to protect themselves. When someone asks for an interview, for example, a scientist should enquire about starting assumptions, the intended audience and the identity of the project's backers. And, if possible, researchers should check the earlier work of the journalists and any companies behind the film for a partisan tone, or unacceptable levels of sensationalism.

But if these efforts fail, and it is discovered too late that the filmmakers are bent on using an on-tape interview to promote a view that seems unscientific, the question becomes what steps to take. There is rarely a way to withdraw an interview that was given on the record, for good reason. In any case, making a fuss can be a gift of publicity to film-makers. Schneider admits that he might have spared himself the deluge of e-mails had he just ignored the makers of Not Evil Just Wrong.

A better approach might well be to complain to the television channels and broadcasting regulators, many of which have standards for their programming. The Great Global Warming Swindle was censured by Ofcom, Britain's broadcasting regulator, for breaking several rules in its broadcasting code. And when the same documentary was aired by the Australian Broadcasting Corporation, it was followed by a point-by-point debate and rebuttal.

In the end, this is perhaps the most effective way to limit the damage. Bad journalism is best met not with red-faced indignation, but with good journalism. The truth is the best revenge. 